\title{
The future of vascular restoration therapy
}

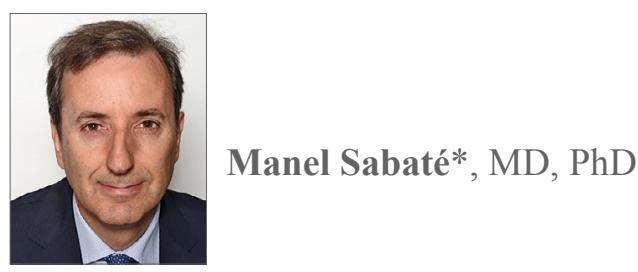

Department of Interventional Cardiology, Cardiovascular Institute, Hospital Clínic, University of Barcelona, Institut d'Investigacions Biomèdiques August Pi I Sunyer (IDIBAPS), Barcelona, Spain

\section{The promise}

The launch of the Absorb ${ }^{\mathrm{TM}}$ (Abbott Vascular, Santa Clara, CA, USA), the world's first drug-eluting poly-L-lactide acid-based (PLLA) bioresorbable vascular scaffold (BVS), in September 2012 was enthusiastically applauded by the interventional cardiology community. The so-called fourth revolution of coronary interventions not only aspired to maintain the favourable acute results of current second-generation drug-eluting stents, but it also sought to improve the long-term clinical outcomes of patients with coronary artery disease. In particular, BVS technology was destined to be able to improve residual angina pectoris and to restore normal coronary vasomotion. Data from the initial ABSORB cohort $B$ registry showed the return of vasomotor function that correlated with reduction in polymeric strut echogenicity ${ }^{1}$. Physicians and scientists were able to demonstrate that the BVS could be resorbed and, subsequently, the vessel could be released from the perpetual caging of metallic drug-eluting stents. Against this background, the concept of vascular restoration therapy (VRT) was capitalised by this new technology and the device was used to this end in different scenarios (ranging from simple to highly complex) without the development of any dedicated implantation technique protocol or even without any consensus regarding the type and duration of the antiplatelet regimen to be prescribed. Furthermore, patients themselves started to ask for an Absorb to be implanted in their own coronary arteries as a pill for eternality.

\section{The evidence}

Several randomised controlled trials were designed to demonstrate the beneficial effect of this new technology scientifically. Most of them were intended to demonstrate non-inferiority at short-term and midterm follow-up but superiority at long-term follow-up as compared to current-generation drug-eluting stents. Early results of the ABSORB II trial apparently supported the concept of angina relief with the use of $\mathrm{BVS}^{2}$. However, this initial finding was soon tarnished by the increased number of both early and very late scaffold thrombosis observed in the Absorb arm ${ }^{3}$. Device-related factors (e.g., strut thickness), procedural factors (e.g., implantation technique not following predilatation, sizing and postdilatation [PSP] criteria, implantation of BVS in small vessels, device rupture in complex procedures, etc.), type and duration of antiplatelet regimen, and metabolic factors ("unhealthy" resorption process causing very late vessel collapse) were ultimately identified as potential causes of scaffold thrombosis at different stages after BVS implantation ${ }^{4-6}$. A number of meta-analyses of all randomised 
trials corroborated the increased risk of myocardial infarction and thrombosis with the use of Absorb $\mathrm{BVS}^{7,8}$. At this point, BVS technology had not been able to demonstrate non-inferiority as compared to standard metallic drug-eluting stents.

Was the promise of vascular restoration therapy accomplished? In the context of randomised data, vasodilatory response to nitroglycerine as a surrogate of endothelium-independent vasomotion was not improved by BVS at three years after its implantation. Therefore, the primary endpoint of the ABSORB II trial was not met ${ }^{9}$. Besides, device remnants were observed by intracoronary imaging techniques and identified in histopathological samples up to four years of follow-up ${ }^{10}$. Therefore, in humans and in the clinical arena there probably exists a delay in the resorption process of the PLLA-based device that may preclude normalising vasoreactivity to stimuli.

Like a house of cards, all hopes fell apart when, as of May 2017, the Absorb BVS was restricted to use only in centres already participating in clinical trials and registries and, ultimately, it was removed from the market.

\section{The future}

We should learn from past failures. From the disappointing results of first-generation BVS, there had emerged signs of green shoots that should be taken into consideration for future improvements in this field. Let's focus first on the device, second on the target, and finally on the concept. The next generation of devices should probably be thinner with initial higher radial force. A dedicated implantation technique should be developed and proven in various clinical settings. The resorption process should be safe, healthy and complete and should not take longer than one year. Target lesions amenable to be treated by this device are those which are soft by nature, with small plaque burden. In this regard, patients suffering from acute coronary syndromes, specifically ST-segment elevation myocardial infarction (STEMI), are those who may benefit most from bioresorbable scaffolds. The TROFI II trial performed in STEMI patients was probably the only randomised trial with reassuring results after BVS implantation up to three-year follow-up ${ }^{11}$. This trial, however, was not powered for clinical events. Recently, a refined PSP-derived implantation algorithm (BVS STEMI STRATEGY-IT) has been validated in the acute phase in this thrombotic context ${ }^{12,13}$. Whether this technique may confer any benefit during the resorption phase of the device remains to be proven. Finally, the concept of vascular restoration therapy should be revisited. In my view, it comprises at least two parts: first, the complete and safe disappearance of the device as mentioned above and, second, the restoration of vascular reactivity and endothelial function leading to prevention of neoatherosclerosis development and atherosclerosis progression. While the former may be achieved by refinement in engineering work, the latter may require a holistic view. A small device intended to be used to relieve an obstructive lesion is not able to cure a systemic disease. Endothelial function is affected by numerous factors including hypertension, dyslipidaemia, diabetes mellitus, chronic renal disease, sepsis, therapeutic hypothermia, chronic inflammatory disease, obesity and smoking, among others ${ }^{14-19}$. The use of preventive measures or pharmacological agents such as statins or ACE inhibitors may ameliorate endothelial dysfunction ${ }^{14,16}$. In 1985, Ludmer et al demonstrated that coronary artery disease was associated with an abnormal vasoconstrictive response to acetylcholine ${ }^{20}$. Therefore, the sole presence of atherosclerotic plaques in the vasculature may preclude vasomotion from recovery. Consequently, the implantation of a bioresorbable device in, for example, a diffusely diseased diabetic patient may not be enough to restore endothelial function in the long term. At three years, in the TROFI II trial, vasoconstriction to acetylcholine and vasodilatation to nitroglycerine were more often observed in the segment treated with BVS than in that with a permanent metallic everolimus-eluting stent, despite the fact that footprints of the implanted polymeric scaffolds were still clearly visible in all lesions treated with $\mathrm{BVS}^{21}$ (Figure 1). Interestingly, the microcirculation dependent on the infarct-related artery showed a preserved index of resistance, coronary flow reserve, fractional

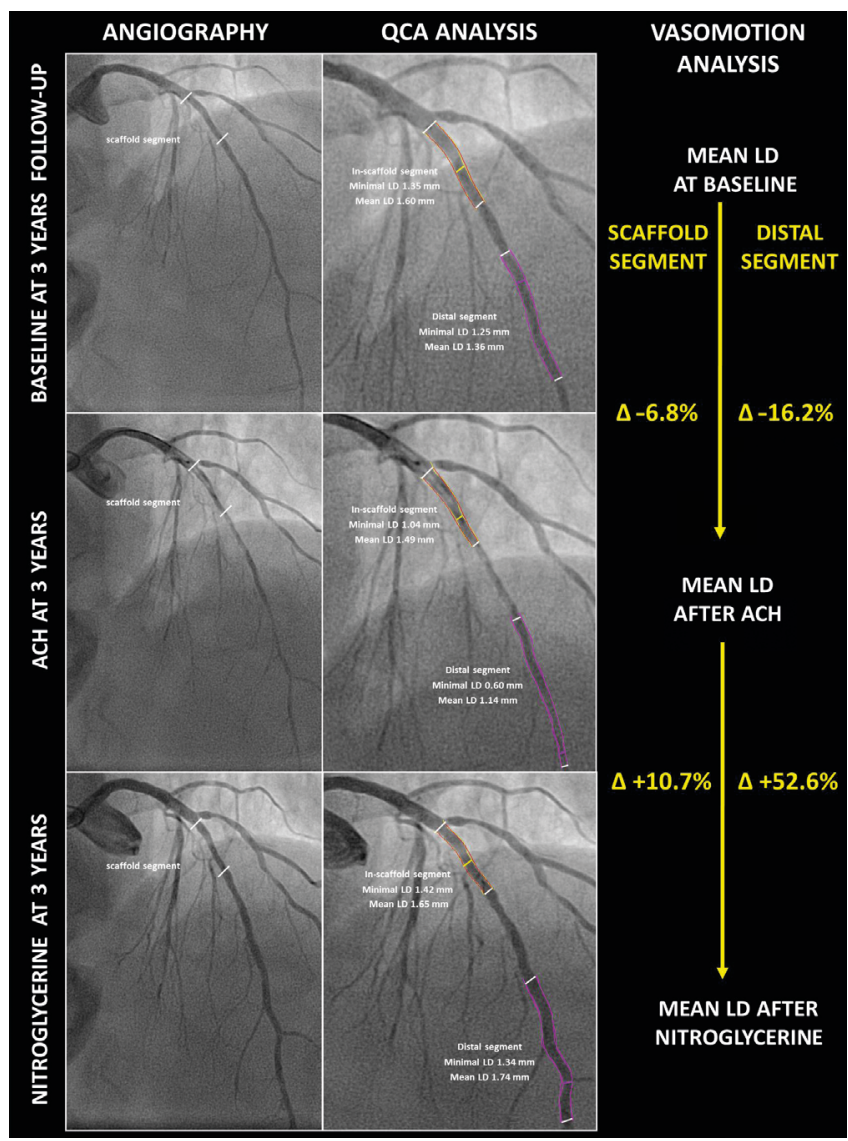

Figure 1. Long-term vasomotor response after BVS implantation. Three-year follow-up of a proximal left anterior descending artery treated with an Absorb BVS scaffold in the STEMI context. At three years, both the scaffold segment and the distal vessel are reactive to acetylcholine (endothelium-dependent vasoconstriction indicative of endothelial dysfunction) and to nitroglycerine (endotheliumindependent vasodilation). ACH: acetylcholine; LD: lumen diameter; QCA: quantitative coronary angiography 
flow reserve and absolute flow. These data support the concept that patients with a small overall plaque burden (e.g., STEMI with only proximal lesions) may be the best candidates for vascular restoration therapy. Neoatherosclerosis development at the scaffolded segment may also be a matter of concern. It has recently been put forward as the second most frequent underlying mechanism of very late scaffold thrombosis (the first being the unfavourable resorption-related process) ${ }^{22}$. Besides, in patients with stable chronic angina treated with BVS from the ABSORB-EXTEND registry, neoatherosclerosis appeared to develop between one and five years in terms of in-scaffold lipid-laden neointima, calcification, neovascularisation, and thin-cap fibroatheroma ${ }^{23,24}$. Notably, these findings were not observed in non-scaffolded segments. Whether chronic inflammatory response during the resorption phase induces such a phenomenon remains to be elucidated but should surely be addressed in any new BVS iteration or new bioresorbable technology (e.g., metallic-based BVS).

In summary, vascular restoration therapy is a complex process in which safe scaffold implantation should be the first step. This has to be followed by a healthy non-inflammatory resorption of the device within a prudent period of 12 months. Concomitantly, a systemic treatment targeted to the underlying chronic disease would be necessary to ameliorate omnipresent endothelial dysfunction demonstrated in patients with coronary risk factors and atherosclerosis.

\section{Conflict of interest statement}

M. Sabaté received consulting fees from Abbott Vascular.

\section{References}

1. Brugaletta S, Heo JH, Garcia-Garcia HM, Farooq V, van Geuns RJ, de Bruyne B, Dudek D, Smits PC, Koolen J, McClean D, Dorange C, Veldhof S, Rapoza R, Onuma Y, Bruining N, Ormiston JA, Serruys PW. Endothelial-dependent vasomotion in a coronary segment treated by ABSORB everolimus-eluting bioresorbable vascular scaffold system is related to plaque composition at the time of bioresorption of the polymer: indirect finding of vascular reparative therapy? Eur Heart J. 2012;33:1325-33.

2. Serruys PW, Chevalier B, Dudek D, Cequier A, Carrié D, Iniguez A, Dominici M, van der Schaaf RJ, Haude M, Wasungu L, Veldhof S, Peng L, Staehr P, Grundeken MJ, Ishibashi Y, GarciaGarcia HM, Onuma Y. A bioresorbable everolimus-eluting scaffold versus a metallic everolimus-eluting stent for ischaemic heart disease caused by de-novo native coronary artery lesions (ABSORB II): an interim 1-year analysis of clinical and procedural secondary outcomes from a randomised controlled trial. Lancet. 2015;385:43-54.

3. Chevalier B, Onuma Y, van Boven AJ, Piek JJ, Sabaté M, Helqvist S, Baumbach A, Smits PC, Kumar R, Wasungu L, Serruys PW. Randomised comparison of a bioresorbable everolimus-eluting scaffold with a metallic everolimus-eluting stent for ischaemic heart disease caused by de novo native coronary artery lesions: the 2-year clinical outcomes of the ABSORB II trial. EuroIntervention. 2016;12:1102-7.
4. Ortega-Paz L, Capodanno D, Gori T, Nef H, Latib A, Caramanno G, Di Mario C, Naber C, Lesiak M, Capranzano P, Wiebe J, Mehilli J, Araszkiewicz A, Pyxaras S, Mattesini A, Geraci S, Naganuma T, Colombo A, Münzel T, Sabaté M, Tamburino C, Brugaletta S. Predilation, sizing and post-dilation scoring in patients undergoing everolimus-eluting bioresorbable scaffold implantation for prediction of cardiac adverse events: development and internal validation of the PSP score. EuroIntervention. 2017;12:2110-7.

5. Ellis SG, Steffenino G, Kereiakes DJ, Stone GW, van Geuns RJ, Abizaid A, Nef H, Cortese B, Testa L, Menichelli M, Tamburino C, Gori T, Kimura T, Serruys PW, Brugaletta S, Sabaté M, Gao RL. Clinical, Angiographic, and Procedural Correlates of Acute, Subacute, and Late Absorb Scaffold Thrombosis. JACC Cardiovasc Interv. 2017;10:1809-15.

6. Ellis SG, Gori T, Serruys PW, Nef H, Steffenino G, Brugaletta S, Munzel T, Feliz C, Schmidt G, Sabaté M, Onuma Y, van Geuns RJ, Gao RL, Menichelli M, Kereiakes DJ, Stone GW, Testa L, Kimura T, Abizaid A. Clinical, Angiographic, and Procedural Correlates of Very Late Absorb Scaffold Thrombosis: Multistudy Registry Results. JACC Cardiovasc Interv. 2018;11:638-44.

7. Ali ZA, Serruys PW, Kimura T, Gao R, Ellis SG, Kereiakes DJ, Onuma Y, Simonton C, Zhang Z, Stone GW. 2-year outcomes with the Absorb bioresorbable scaffold for treatment of coronary artery disease: a systematic review and meta-analysis of seven randomised trials with an individual patient data substudy. Lancet. 2017;390: 760-72.

8. Ali ZA, Gao R, Kimura T, Onuma Y, Kereiakes DJ, Ellis SG, Chevalier B, Vu MT, Zhang Z, Simonton CA, Serruys PW, Stone GW. Three-Year Outcomes With the Absorb Bioresorbable Scaffold: Individual-Patient-Data Meta-Analysis From the ABSORB Randomized Trials. Circulation. 2018;137:464-79.

9. Serruys PW, Chevalier B, Sotomi Y, Cequier A, Carrié D, Piek JJ, Van Boven AJ, Dominici M, Dudek D, McClean D, Helqvist S, Haude M, Reith S, de Sousa Almeida M, Campo G, Iñiguez A, Sabaté M, Windecker S, Onuma Y. Comparison of an everolimus-eluting bioresorbable scaffold with an everolimus-eluting metallic stent for the treatment of coronary artery stenosis (ABSORB II): a 3 year, randomised, controlled, single-blind, multicentre clinical trial. Lancet. 2016;388:2479-91.

10. Räber L, Brugaletta S, Yamaji K, O’Sullivan CJ, Otsuki S, Koppara T, Taniwaki M, Onuma Y, Freixa X, Eberli FR, Serruys PW, Joner M, Sabaté M, Windecker S. Very Late Scaffold Thrombosis: Intracoronary Imaging and Histopathological and Spectroscopic Findings. J Am Coll Cardiol. 2015;66:1901-14.

11. Sabaté $M$, Windecker $S$, Iñiguez A, Okkels-Jensen $L$, Cequier A, Brugaletta S, Hofma SH, Räber L, Christiansen EH, Suttorp M, Pilgrim T, Anne van Es G, Sotomi Y, García-García HM, Onuma Y, Serruys PW. Everolimus-eluting bioresorbable stent vs. durable polymer everolimus-eluting metallic stent in patients with ST-segment elevation myocardial infarction: results of the randomized ABSORB ST-segment elevation myocardial infarctionTROFI II trial. Eur Heart J. 2016;37:229-40. 
12. Ielasi A, Campo G, Rapetto C, Varricchio A, Cortese B, Brugaletta S, Geraci S, Vicinelli P, Scotto di Uccio F, Secco GG, Poli A, Nicolini E, Ishida K, Latib A, Tespili M. A Prospective Evaluation of a Pre-Specified Absorb BVS Implantation Strategy in ST-Segment Elevation Myocardial Infarction: The BVS STEMI STRATEGY-IT Study. JACC Cardiovasc Interv. 2017;10:1855-64.

13. Sabaté M. Bioresorbable Vascular Scaffold Implantation: To Whom and How? JACC Cardiovasc Interv. 2017;10:1865-6.

14. Iràculis E, Cequier A, Sabaté M, Pintó X, Gómez-Hospital JA, Mauri J, García Del Blanco B, Fernández-Nofrerias E, Palom X, Jara F, Esplugas E. [Improvement of endothelial function in patients with hypercholesterolemia and normal coronary arteries with lipidlowering therapy]. [Article in Spanish]. Rev Esp Cardiol. 2001;54: 685-92.

15. Brugaletta S, Scalone G, Dantas AP, Ortega-Paz L, Garabito M, Roqué M, Martin V, Masotti M, Freixa X, Sabaté M. Endothelial function impairment in STEMI patients with out-ofhospital cardiac arrest under therapeutic hypothermia treatment. Int J Cardiol. 2017;232:70-5.

16. Nevelsteen I, Van den Bergh A, Van der Mieren G, Vanderper A, Mubagwa K, Bult H, Herijgers P. NO-dependent endothelial dysfunction in type II diabetes is aggravated by dyslipidemia and hypertension, but can be restored by angiotensin-converting enzyme inhibition and weight loss. J Vasc Res. 2013;50:486-97.

17. Kopel T, Kaufman JS, Hamburg N, Sampalis JS, Vita JA, Dember LM. Endothelium-Dependent and -Independent Vascular Function in Advanced Chronic Kidney Disease. Clin J Am Soc Nephrol. 2017;12:1588-94.

18. Messner B, Bernhard D. Smoking and cardiovascular disease: mechanisms of endothelial dysfunction and early atherogenesis. Arterioscler Thromb Vasc Biol. 2014;34:509-15.

19. Iantorno M, Campia U, Di Daniele N, Nistico S, Forleo GB, Cardillo C, Tesauro M. Obesity, inflammation and endothelial dysfunction. J Biol Regul Homeost Agents. 2014;28:169-76.
20. Ludmer PL, Selwyn AP, Shook TL, Wayne RR, Mudge GH, Alexander RW, Ganz P. Paradoxical vasoconstriction induced by acetylcholine in atherosclerotic coronary arteries. $N$ Engl J Med. 1986;315:1046-51.

21. Gomez-Lara J, Brugaletta S, Ortega-Paz L, Vandeloo B, Moscarella E, Salas M, Romaguera R, Roura G, Ferreiro JL, Teruel L, Gracida M, Windecker S, Serruys PW, GomezHospital JA, Sabaté M, Cequier A. Long-Term Coronary Functional Assessment of the Infarct-Related Artery Treated With EverolimusEluting Bioresorbable Scaffolds or Everolimus-Eluting Metallic Stents: Insights of the TROFI II Trial. JACC Cardiovasc Interv. 2018;11:1559-71.

22. Yamaji K, Ueki Y, Souteyrand G, Daemen J, Wiebe J, Nef H, Adriaenssens T, Loh JP, Lattuca B, Wykrzykowska JJ, GomezLara J, Timmers L, Motreff P, Hoppmann P, Abdel-Wahab M, Byrne RA, Meincke F, Boeder N, Honton B, O'Sullivan CJ, Ielasi A, Delarche N, Christ G, Lee JKT, Lee M, Amabile N, Karagiannis A, Windecker S, Räber L. Mechanisms of Very Late Bioresorbable Scaffold Thrombosis: The INVEST Registry. $J$ Am Coll Cardiol. 2017;70:2330-44.

23. Moriyama N, Shishido K, Tanaka Y, Yokota S, Hayashi T, Miyashita H, Koike T, Yokoyama H, Takada T, Nishimoto T, Ochiai T, Tobita K, Yamanaka F, Mizuno S, Murakami M, Takahashi S, Saito S. Neoatherosclerosis 5 Years After Bioresorbable Vascular Scaffold Implantation. J Am Coll Cardiol. 2018; 71:1882-93.

24. Zeng Y, Tateishi H, Cavalcante R, Tenekecioglu E, Suwannasom P, Sotomi Y, Collet C, Nie S, Jonker H, Dijkstra J, Radu MD, Räber L, McClean DR, van Geuns RJ, Christiansen EH, Fahrni T, Koolen J, Onuma Y, Bruining N, Serruys PW. Serial Assessment of Tissue Precursors and Progression of Coronary Calcification Analyzed by Fusion of IVUS and OCT: 5-Year Follow-Up of Scaffolded and Nonscaffolded Arteries. JACC Cardiovasc Imaging. 2017;10:1151-61. 


\section{EAPCI}

-

TAKE THE NEXT STEP

- Join your community

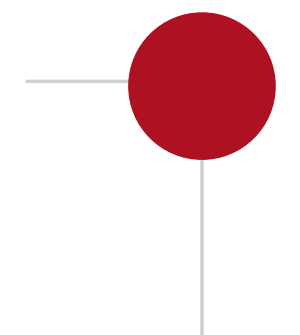

Enhance your career and get your science recognised

Get exclusive access to EAPCI educational products and training opportunities in centres of excellence

Get one-off reduced subscription rate for Eurolntervention Journal (print version)

Access the Community's networks on Linkedln

EAPCI, the leading network of experts in Interventional Cardiology www.escardio.org/EAPCI-membership

W A T Mix and match the ESC membership MORE? packages that best suit your needs for unique savings and benefits. 